Published May 31, 2016

\title{
Nonhuman Primates and Humanized Mice FOR STUdies OF HIV-1 INTEgRASE INHIBITORS: A REVIEW
}

\section{AUTHORS}

Said A. Hassounah ${ }^{1,2}$, Thibault Mesplède ${ }^{2}$, Mark A. Wainberg ${ }^{1,2,3}$

\section{AFFILIATED INSTITUTIONS}

${ }^{1}$ McGill University AIDS Centre, Lady Davis Institute for Medical Research, Jewish General Hospital, Montréal, Québec, Canada

${ }^{2}$ Division of Experimental Medicine, Faculty of Medicine, McGill University, Montréal, Québec, Canada

${ }^{3}$ Division of Microbiology and Immunology, Faculty of Medicine, McGill University, Montréal, Québec, Canada

\section{CORRESPONDING AUTHOR}

Mark A. Wainberg

mark.wainberg@mcgill.ca

+15143408222 x5282

\section{ABSTRACT}

Since the discovery of the first inhibitors of HIV replication, drug resistance has been a major problem in HIV therapy due in part to the high mutation rate of HIV. Therefore, the development of a predictive animal model is important to identify impending resistance mutations and to possibly inform treatment decisions. Significant advances have been made possible through use of nonhuman primates infected by SIV, SHIV, and simian-tropic HIV-1 (stHIV-1), and use of humanized mouse models of HIV-1 infections. In this review, we describe some of the findings from animal models used for the preclinical testing of integrase strand transfer inhibitors. These models have led to important findings about the potential role of integrase strand transfer inhibitors in both the prevention and treatment of HIV-1 infection.

Keywords: nonhuman primates, integrase strand transfer inhibitors, integrase, drug resistance mutations, simian immunodeficiency virus (SIV), simian-human immunodeficiency virus (SHIV), simian-tropic human immunodeficiency virus (stHIV-1) 


\section{BACKGROUND}

Simian immunodeficiency virus (SIV) is naturally endemic to a wide variety of African nonhuman primates (NHPs). In its natural host, sooty mangabeys (Cercocebus atys; SM) and African green monkeys (Chlorocebus sabaeus; AGM), SIV infection is nonpathogenic. Notably, SIV replicates actively in infected NHPs, but unlike HIV-1 infected individuals, these animals do not generally develop immunodeficiency-like symptoms $[1,2]$.

Following an accidental cross-species transmission of a variant of SIV termed SIVsm to rhesus macaques, a lethal disease was observed in these hosts with symptoms similar to AIDS [3-8]; this has given rise to the pathogenic SIVmac strain [ $[5,9]$. Cross-species transmissions from chimpanzees and SMs to humans have given rise to HIV-1 and HIV-2, respectively [10-12]. Chimpanzees have been found to develop simian AIDS (SAIDS) when naturally infected with SIVcpz, a virus that infects Central African chimpanzees (Pan troglodytes troglodytes) [13]. Although HIV-1 and SIVcpz share a very high degree of similarity, chimpanzees are not convenient NHP models due to their endangered status and high maintenance costs.

SAIDS and human AIDS share similar symptoms that include acute and progressive loss of CD4 ${ }^{+}$ $\mathrm{T}$ cells followed by immunodeficiency, opportunistic infections, and development of tumors [14]. Routes of transmission of SIV infections in chimpanzees and macaques are similar to HIV infections in humans and include mucosal spread via vaginal [15], rectal [16], and penile routes [17] or oropharyngeal transmission in neonates [18].

Through the use of highly active antiretroviral therapy (HAART), HIV-1 infection has become manageable and is often now a chronic disease. HAART provides treatment options for both treatment-naïve and treatment-experienced patients. There are six classes of antiretroviral agents that can be used, and these are often combined in treatment. These include nucleoside reverse transcriptase inhibitors (NRTIs), non-nucleoside reverse transcriptase inhibitors (NNRTIs), protease inhibitors (PIs), integrase strand transfer inhibitors (INSTIs), fusion inhibitors (FIs), and chemokine receptor antagonists (CCR5 antagonists).

INSTIs are the most recent class of antiretroviral (ARV) drugs and include the FDA-approved agents raltegravir (RAL), elvitegravir (EVG), and dolutegravir (DTG). A new investigational INSTI, cabotegravir, which is an analog of DTG, is being developed as an oral tablet for once daily dosing and can be administered as a long-acting parenteral formulation (cabotegravir LA).

All integrase inhibitors approved to date inhibit the integration process $[19,20]$. Integration into host cell DNA is the last step performed by the HIV and SIV integrase proteins before an irreversible infection takes place in a cell. Integration occurs via two reactions that are catalyzed by the viral integrase (IN) enzyme following reverse transcription. First, IN cleaves a dinucleotide from each viral DNA terminus (long terminal repeat [LTR]) to produce reactive 3 '-end processed DNA (a step referred to as $3^{\prime}$ processing), which is then covalently linked to the host DNA in a process known as strand transfer [21, 22]. IN contains three domains: $\mathrm{N}$-terminal, catalytic core (cc), and $\mathrm{C}$-terminal domains. Each domain is essential for integration. The catalytic core domain encompasses the catalytic triad-Asp ${ }_{64}, \mathrm{Asp}_{116}$, and $\mathrm{Glu}_{152}\left(\mathrm{D}_{64} \mathrm{D}_{116} \mathrm{E}_{152}\right)$ - that coordinates two divalent metal cations $\left(\mathrm{Mg}^{2+}\right.$ or $\left.\mathrm{Mn}^{2+}\right)$. INSTIs function by disrupting the interaction between IN and viral and/or target DNA and/or chelating metal ions in the catalytic core domain [23]. Sequence alignments of the IN proteins of different SIV isolates with various groups of HIV-1 show high 
sequence conservation of the catalytic triad and key residues involved in resistance to INSTIs (Figure 1) [24]. Amino acids E92, T97, G118, F121, G140, Y143, S147, Q148, N155, and R263 are conserved among HIV-1, HIV-2, and different SIVs [25, 26].

HIV-1_subtype_B
HIV-2
SIVgor
SIVcpz
SIVmac
SIVagm

HIV-1_subtype_B
HIV-2
SIVgor
SIVcpz
SIVmac
SIVagm
HIV-1_subtype_B
HIV-2
SIVgor
SIVcpz
SIVmac
SIVagm

1 FLDGIDKAQEDHERYHSNWRTMASDFNLPPVVAKEIVASCDKCQVKGEAIHGQVDCSPGI 60 1 FLEKIEPAQEEHEKYHSNVKELSHKFRLPKLVARQIVNTCAQCQQKGEAIHGQVNAELGT 60 1 FLEGIDQAQEDHEKYHSNWRTLASDFGLPPVVAKEIINSCPKCHVKGEARHGQVDCSPGI 60 1 FLDGINEAQEDHDKYHSNWKALADEYNLPPVVAKEI IAQCPKCHIKGEAIHGQVDYSPEI 60 1 FLEKIEPAQEEHDKYHSNVKELVFKFGLPRIVARQIVDTCDKCHQKGEAIHGQVNSDLGT 60 1 FLDRMEEAQESHDKYHTNWQFIRDAFGI PALVAKEIVAACPKCQIRGEPIHGQVDASVGV 60

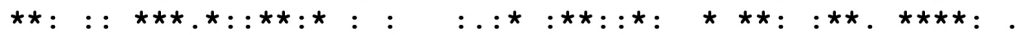

61 WQLDCTHLEGKIILVAVHVASGYIEAEVIPAETGQETAYFILKLAGRWPVKTIHTDNGSN 120 61 WQMDCTHLEGKVIIVAVHVASGFIEAEVIPQETGRQTALFLLKLASRWPITHLHTDNGAN 120 61 WQLDCTHLEGKIILVAVHVASGFIEAEVIPAETGQETAYFLLKLAARWPVKIIHTDNGPN 120 61 WQIDCTHLEGKVIIVAVHVASGFIEAEVIPEETGRETAYFILKLAGRWPVKKIHTDNGPN 120 61 WQMDCTHLEGKIIIVAVHVASGFIEAEVIPQETGRQTALFLLKLAGRWPITHLHTDNGAN 120 61 WQMDCTHLEGKIIIVAVHVASGFLEAEVIARETGKETAKFLLKIISRWPITKLHTDNGPN 120

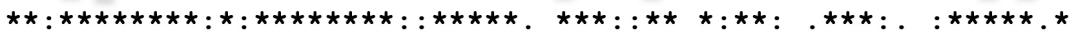

121 FTSTTVKAACWWAGVKQEFGIPYNPQSQGVVESMNKELKKIIGQVRDQAEHLKTAVQMAV 180 121 FTSQEVKMVAWWIGIEQSFGVPYNPQSQGVVEAMNHHLKNQISRIREQANTVETIVLMAV 180 121 FTSATVKAACWWLNVTHEFGIPYNPQSQGVVESMNKELKKIIQQVRDQAEHLKTAVQMAV 180 121 FTSTAVKAACWWAQIQHEFGIPYNPQSQGVVESMNKQLKQIIEQVRDQAEQLRTAVIMAV 180 121 FASQEVKMVAWWAGIEHTFGVPYNPQSQGVVEAMNHHLKNQIDRIREQANSVETIVLMAV 180 121 FVSQEVQTICWWGQVEHTTGIPYNPQSQGSVESMNRQLKETIEKIREDCAFLETAVLMAC 180

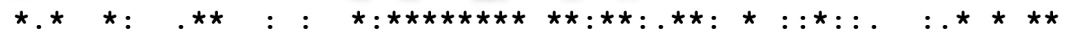

181 FIHNFKRKGGIGGYSAGERIIDIIATDIQTKELQKQITKVQNFRVYYRDNRDPLWKGPAK 240 181 HCMNFKRRGGIGDMTPSERLINMITTEQEIQFLQAKNSKLKNFRVYFREGRDQLWKGPGE 240 181 FVHNFKRKGGIGGYTAGDRIIDMLATQIQTTELQKQILKIQNFRVYYRDSRDPIWKGPAT 240 181 YIHNFKRKGGIGEYTAGERLLDILTTNIQTKQLQKQILKVQNFRVYYRDARDPIWKGPAR 240 181 HSMNFKRRGGTGDMTPAERLINMITTEQEIQFQQSKNSKFKNFRVYYREGRDQLWKGPGE 240 181 HIHNFKRKGGIGGMTPAERLINMITTQLEIQHIQTQQQKISNFKVYYREGREPVWKGPAT 240

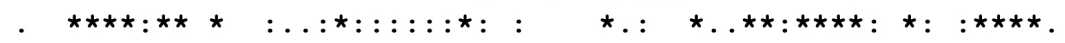

241 LLWKGEGAVVIQDNSEIKVVPRRKAKIIRDYG--KQMAGDDCVASXQDED------- 288 241 LLWKGDGAVIVKVGTDIKIIPRRKAKIIRDYGGRQEMDSGPHLEGTREDGEVA------- 293 241 LLWKGEGAVVIQDKGDIKVVPRRKAKIIRDYG--KQMAGDDCVADTQGESESLEQSS 295 241 LLWKGEGAVVIKEGEDIKVVPRRKAKIIKEYG--KQMAGAGGMDDRQNET------- 288 241 LLWKGEGAVILKVGTDIKVVPRRKAKIIKDYGGGKEMDSSSHMEDTGEAREVA---- 293 241 LLWKGEGAVVIKEGEELKVVPRRKAKIIKEYGERKTVGDKTNMEG---------- 285 $\star \star \star \star \star \star \star \star \star::: \quad:: \star \star \star \star \star \star \star \star \star \star \star:: \star \star \quad \star:$ : $:$.

Figure 1. Multiple amino acid sequence alignment of HIV-1 subtype B and different SIV integrases. The HIV-1 subtype B integrase sequence is provided as a reference. Identical amino acid residues that are conserved across all six proteins are marked with an asterisk $\left.{ }^{*}\right)$; residues similar to each other are marked with a colon (:); those that are less similar are marked with a period (.); and those that are not similar are not marked. Catalytic triad residues (D64, D116, and E152) and residues involved in main resistance pathways against integrase inhibitors (T66, E92, T97, G118, F121 G140, Y143, S147, Q148, N155, and R263) are shaded in gray. The GenBank accession numbers for the sequences used in this alignment are DQ676870 (HIV-1 subtype B), DQ307022 (HIV-2) FJ424864 (SIV gor CP2139.1con), EF394356.1

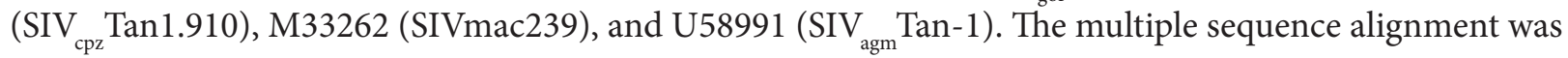
performed using Clustal Omega software [27-29]. 
In clinical trials, four primary major resistance pathways confer cross resistance to RAL and EVG, and these include substitutions at positions E92Q, Y143R, Q148R/K/H, and N155H, as well as other mutations. Q148 plus two or more additional substitutions can also decrease the clinical efficacy of DTG [풍.

\section{ANIMAL MODELS}

Several key factors must be taken into account when choosing an animal model for the study of HIV-1 pathogenesis (Table 1). These include the use of the CD4 receptor and the use of either the CC-chemokine receptor 5 (CCR5) or the CXC-chemokine receptor 4 (CXCR4) as co-receptors, nuclear export factors, transcription factors, and cellular host factors [ $\underline{31}]$. The most suitable animal models that have received broad acceptance in the HIV field include humanized mice, nonhuman primates (macaques), and to some extent cats. Although not commonly used, the feline model was valuable in the development of one of the most commonly used ARVs, tenofovir (TFV; NRTI) [32-35]. Previous research showed that feline immunodeficiency virus (FIV) DNA integration into the host cell genome can be inhibited by the INSTI naphthyridine carboxamide, L-870810, and this resulted in attenuated replication in the feline lymphoid cell line MBM [ $\underline{34}$, 36]. Animal models are important for preclinical drug testing, the demonstration of the benefits of early treatment, and the significance of drug resistance mutations.

\section{BLT and SCID-hu Mice}

HIV-1 cannot ordinarily infect rodents due to the inability of the HIV-1 envelope (env) to utilize rodent cell surface molecules for binding and entry [37] and the inability of the murine cyclin T1 protein to associate with HIV-1 Tat [38]. However, two mouse models have been developed that are now important tools for HIV research. The bone, liver, and thymus (BLT) model involves the transplantation of bone marrow, liver, and thymus tissues from humans into mice. Another model is the severe combined immunodeficiency (SCID-hu) mouse in which mice are homozygous for the SCID defect $[\underline{39}, \underline{40}]$. This model is constructed by implanting human fetal liver and thymus under the mouse kidney capsule. Since tissue transplantation allows for HIV-1 to infect mice, many aspects of HIV-1 pathogenesis, transmission, and tissue dissemination can be addressed using these models.

Following infection with CCR5- or CXCR4-tropic HIV, successful reproduction of HIV-1 pathogenesis in humanized mice with substantial plasma viremia and systemic depletion of human $\mathrm{CD}^{+} \mathrm{T}$ cells was observed $[\underline{41}, \underline{42}]$. 
Table 1. Advantages and disadvantages of surrogate models and challenge viruses for HIV1 Infection

\begin{tabular}{|c|c|c|}
\hline $\begin{array}{c}\text { Surrogate } \\
\text { Models for HIV- } \\
1 \text { Infection }\end{array}$ & Advantages and Uses & Disadvantages \\
\hline Cat & $\begin{array}{l}\text { - Sensitivity of FIV RT in infected cats to adefovir }(\mathrm{N}[\mathrm{t}] \\
\text { RTI) helped lead to the development of Tenofovir } \\
{[\underline{35}, \underline{43}, \underline{44}]} \\
\text { - Susceptible to integrase inhibitors }[\underline{33}, \underline{34}]\end{array}$ & $\begin{array}{l}\text { - Limited sensitivity to NNRTIs } \\
\text { and PIs [ } \underline{45}] \\
\text { - Lacks certain genes found in } \\
\text { HIV ( } v p r, v p u, \text { Tat, nef) } \\
\text { - Uses CD134 as a primary re- } \\
\text { ceptor instead of CD4 [ㅌ] } \\
\text { - FIV can infect CD8 }{ }^{+} \text {T cells } \\
\text { and B cells }\end{array}$ \\
\hline Humanized mice & $\begin{array}{l}\text { - Direct injection using HIV-1 } \\
\text { - Informative studies demonstrating the efficacy of } \\
\text { antiretroviral therapy [47-51] }\end{array}$ & $\begin{array}{l}\text { - Limitation for studying muco- } \\
\text { sal transmission of HIV-1 } \\
\text { - Cannot fully recapitulate dy- } \\
\text { namics of HIV-1 pathogenesis } \\
\text { - Cannot be bred } \\
\text { - These animals are immuno- } \\
\text { compromised before initiation } \\
\text { of studies }\end{array}$ \\
\hline $\begin{array}{l}\text { Nonhuman primates } \\
\text { (macaques) }\end{array}$ & $\begin{array}{l}\text { - Infection progresses to simian AIDS } \\
\text { - Establishment of viral reservoirs } \\
\text { - Documentation of elite controllers and long-term } \\
\text { nonprogressors } \\
\text { - Virological suppression achieved when ARVs are } \\
\text { used } \\
\text { - Pigtail macaques mimic the menstrual cycle of hu- } \\
\text { mans } \\
\text { - Early seeding of viral reservoirs prior to viremia [ } \underline{52}]\end{array}$ & $\begin{array}{l}\text { - Disease progression can be } \\
\text { faster than in humans } \\
\text { - SIV and SHIV replication } \\
\text { efficiency and pathogenesis are } \\
\text { species dependent }\end{array}$ \\
\hline
\end{tabular}

(Table continued on the next page) 


\begin{tabular}{|c|c|c|}
\hline Challenge Virus & Advantages and Uses & Disadvantages \\
\hline SIV & $\begin{array}{l}\text { - Sensitive to INSTIs }[\underline{25}, \underline{26}, \underline{53}] \\
\text { - Can be used for preclinical selection for integrase } \\
\text { resistant mutants }[\underline{53}, \underline{54}] \\
\text { - Utilizes CD4 } 4^{+} \text {CCR } 5 \text { T cells for replication }\end{array}$ & $\begin{array}{l}\text { - Limited sensitivity to NNRTIs } \\
\text { and PIs }[26, \underline{55]} \\
\text { - Encodes for } v p x \text { and not the } \\
v p u \text { accessory gene } \\
\text { - Lower sequence homology in } \\
\text { some genes than for HIV } \\
\text { - Inability to replicate in human } \\
\text { cells/cell lines } \\
\text { - Most SIVs cannot use CXCR4 } \\
\text { - Pathogenesis is species depen- } \\
\text { dent }\end{array}$ \\
\hline SHIV & $\begin{array}{l}\text { - RT-SHIVs (contain HIV-1 RT gene) are sensitive to } \\
\text { NNRTIs } \\
\text { - Can investigate CCR5 and/or CXCR4 inhibitors and } \\
\text { HIV-based vaccines using Env-SHIV (R5 and X4 } \\
\text { tropic) } \\
\text { - Env-SHIV can be used to study early events following } \\
\text { transmission }\end{array}$ & $\begin{array}{l}\text { - Lower sequence homology in } \\
\text { some genes than for HIV } \\
\text { - Pathogenesis is species depen- } \\
\text { dent }\end{array}$ \\
\hline $\begin{array}{l}\text { Simian tropic-HIV } \\
\text { (stHIV-1) }\end{array}$ & $\begin{array}{l}\text { - Genome is } 88 \% \text { HIV-1 derived [ } \underline{56}] \\
\text { - Ability to infect and replicate in both human and } \\
\text { rhesus cells by evading restriction factors }[\underline{56}, \underline{57}]\end{array}$ & $\begin{array}{l}\text { Inability to initiate peritoneal } \\
\text { infection of various macaques }\end{array}$ \\
\hline
\end{tabular}

\section{Nonhuman Primate Models}

The use of animal models has helped in the preclinical evaluation and development of antiretroviral therapy (ART) and potential vaccines. Despite their genetic proximity to humans that makes them ideal as animal models for infectious diseases, the utilization of chimpanzees and gorillas poses ethical, scientific, and economic problems, with the use of the former having been mostly restricted for study of hepatitis B, C, and E viruses [ $\underline{58}, \underline{59}]$. Three macaque species have been widely used to investigate aspects of SIV infection that include viral dynamics, immune responses, and changes in $\mathrm{CD}^{+}{ }^{+} \mathrm{T}$ cells to shed light on mechanisms of HIV-1 pathogenicity, transmission, prevention, and therapy. Although macaques are genetically more distant from humans than chimpanzees, they are widely used because they are small, easy to handle, and immunologically similar to humans. These species are rhesus (Macaca mulatta), cynomolgus (Macaca fascicularis), and pigtail (Macaca nemestrina) macaques [44]. These nonhuman primates are also anatomically and genetically closer to humans than cats and mice. Rhesus macaques are seasonal breeders, whereas pigtail macaques are similar to humans with lunar menstrual cycles and changes in hormone levels [60]. As a result, pigtail macaques are more suited than other macaques to capture potential fluctuations in susceptibility to SIV infection that are associated with different phases of the menstrual cycle [61-63]. 
All the aforementioned species are susceptible to SIV infection and develop AIDS-like disease, but rhesus macaques have been most widely used for SIV infection and have provided insights to viral transmission, pathogenesis, and latency $[\underline{3}, \underline{64}]$. A low-dose virus challenge macaque model has several advantages that include the following features: a simian-human immunodeficiency viruses (SHIV) inoculum dose similar to physiological HIV-1 RNA levels found in semen, twice

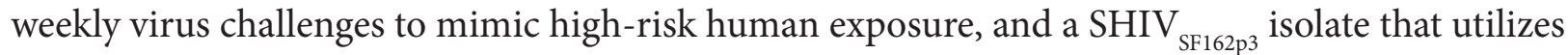
an R5-tropic envelope similar to that found in most HIV-1 transmissions [65-68]. Intrarectal SIV challenge of rhesus macaques has demonstrated that the viral reservoir is rapidly seeded prior to viremia in macaques even when animals were treated with suppressive antiretroviral drugs shortly after infection [52].

\section{SIMIAN VIRAL AND CHIMERIC CONSTRUCTS}

SIV and chimeric viral constructs have been engineered with different HIV genes cloned into SIV backbones to yield SHIVs [무] . The reverse has also been done, giving rise to simian-tropic HIV (stHIV-1) [6]. The genomic organization of HIV-1, HIV-2, SIV, SHIV and stHIV-1 viral genomes is shown in Figure 2.

The HIV genome contains three major genes that encode major structural proteins and enzymes essential for replication: gag, pol, and env. In addition, the HIV genome contains the essential regulatory elements, tat and $r e v$, as well as accessory regulatory proteins, nef, vpr, vif, and $v p u$. SIV has a similar genetic makeup as HIV except that it lacks the $v p u$ gene. It encodes an additional $v p r$-related protein that is termed $v p x$ that functions in association with $v p r$. Similar to HIV, SIV is unable to replicate unless integration of viral DNA takes place. Although most HIV-1 and SIV isolates use the CCR5 co-receptor to gain entry into cells, HIV-1 can acquire the ability to utilize CXCR4, whereas SIV rarely gains this ability but can utilize other co-receptors [70]. Some of the advantages and disadvantages of different viral strains and constructs are highlighted in Table 1.

The SIV/SHIV macaque model has been shown to be superior to mouse models and other nonhuman primates. Both HIV and SIV infections share similarities that include: 1 . viral replication is suppressed by ART; 2. reservoirs of latently infected cells can persist post ART; 3. the course of viremia is characterized by an acute peak followed by a post-peak decline [71]; 4 . viral transmission can occur through vaginal and rectal routes, mimicking the sexual transmission of HIV-1, or by oral routes, mimicking the transfer of virus via breast milk from mother to child; 5 . the primary targets of infection are memory $\mathrm{CD} 4{ }^{+} \mathrm{CCR} 5^{+} \mathrm{T}$ cells; 6 . the major restriction factors that protect cells against viral replication are similar (e.g., tetherin, APOBEC3, SAMHD1, and TRIM5 $\alpha$ ); 7. there are both elite controllers and long-term nonprogressors [71]; 8. life-threatening opportunistic infections are associated with progressive failure of the immune system. 
HIV-1/SIVcpz
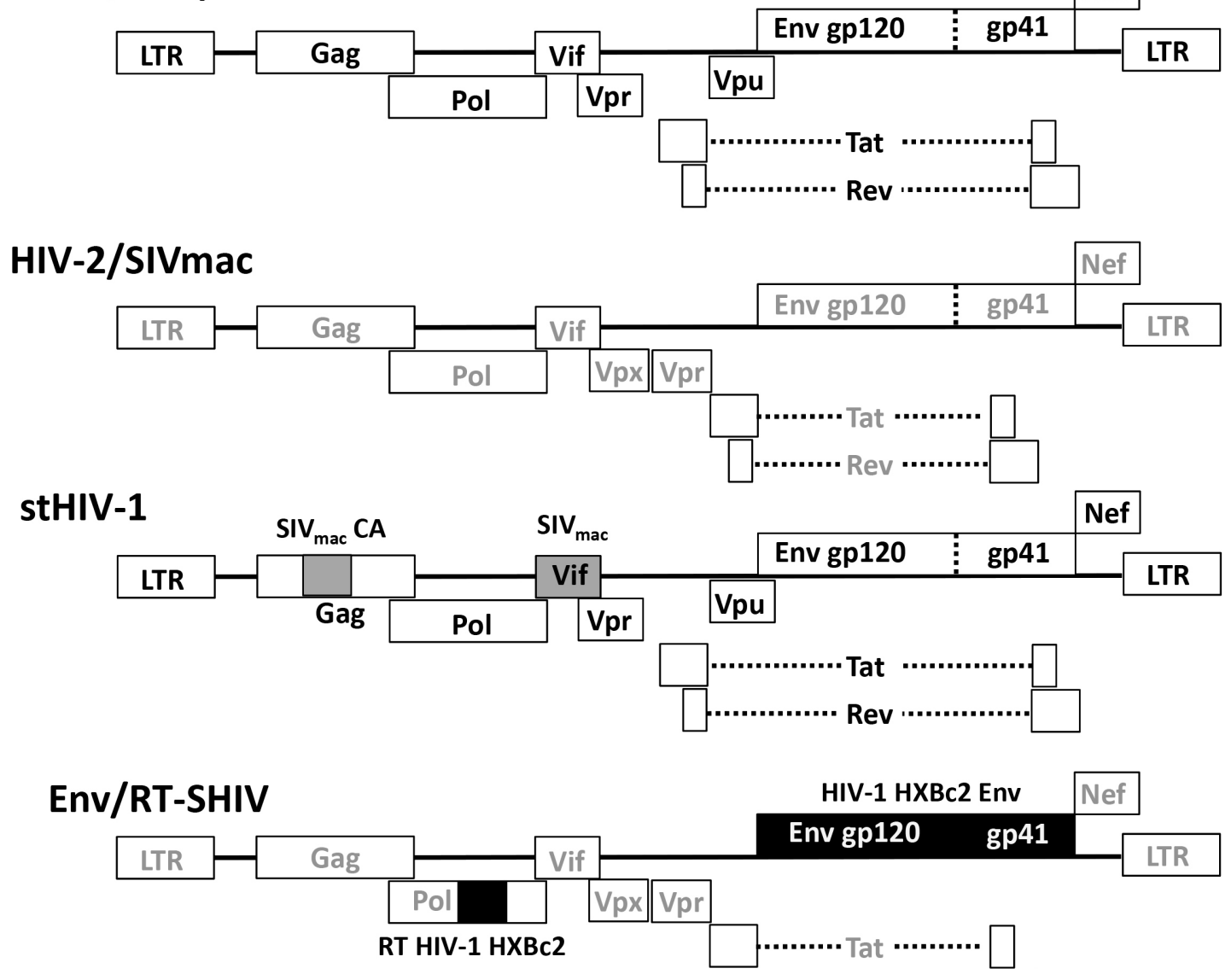

Figure 2. Schematic diagram of the genomic organization of HIV-1, HIV-2, SIV, stHIV-1 and SHIV viral genomes. HIV-1/SIVcpz encodes the $v p u$ gene but lacks the $v p x$ gene. HIV-2/SIVmac encodes $v p x$ but not $v p u$. The gag polyprotein encodes matrix (MA), capsid (CA), and nucleocapsid (NC). The pol genomic region encodes the viral enzymes protease (PR), reverse transcriptase (RT), and integrase (IN). Gray- and black-shaded boxes indicate SIV- and HIV-derived sequences, respectively. Abbreviations: SIV, simian immunodeficiency virus; stHIV-1, simian-tropic human immunodeficiency virus; SHIV, simian-human immunodeficiency virus; SIVcpz, chimpanzee-derived; SIVmac, macaque-derived; RT, reverse transcriptase; LTR, long-terminal repeat; env, envelope glycoprotein.

\section{SIV}

The two most commonly used challenge SIV strains in nonhuman primates are SIVmac251 and SIVmac239, which were isolated from their natural host, the rhesus macaques. These viruses are able to cause high viral loads with minimal variations between animals. SIVmac239 was derived from SIVmac251 by animal passage and tissue culture proviral DNA cloning [9]. These viruses are widely used since they are susceptible to NRTIs, some PIs, and INSTIs, while showing relative lack of sensitivity to NNRTIs $[\underline{25}, \underline{26}, \underline{55}]$.

A three-dimensional (3D) structure solved by X-ray diffraction with a $3 \AA$ resolution of the SIVmac251 IN containing the solubility mutation F185H shows a contiguous core and DNA-bind- 
ing domain (DBD) encompassing amino acid residues 50-293 (containing the catalytic core and C-terminal) in a single polypeptide chain (Protein Data Bank [PDB] ID 1C6V) [그, 73]. This structure shows high conservation of secondary structures (specifically in the catalytic core domain) in comparison to other retroviral Ins, including HIV-1 IN [72]; the susceptibility of SIV to different INSTIs can be attributed to the conservation of the catalytic core domain and key residues of IN.

\section{SHIV Expressing HIV-1 env}

SHIVs expressing HIV-1 env have been widely used as challenge viruses for testing the efficacy of potential vaccines, topical microbicides, entry inhibitors, and fusion inhibitors to block viral transmission. Different SHIV viruses were designed to answer key aspects of HIV-1 replication and infection. SHIVs have also been used to assess ARVs. In recent experiments, SHIVs utilizing any of CXCR4, CCR5, or both as co-receptors have been studied. SHIV ${ }_{89.6 \mathrm{P}}$ is a pathogenic CXCR4 tropic SHIV clone that contains tat, rev, vpu, and the env gene of HIV-1 in a SIVmac239 background [74]; this SHIV displays a different phenotype in macaques compared to HIV-1 and SIV infections in humans and macaques, respectively [75]. The CCR5-tropic virus, SHIV ${ }_{162 \mathrm{P} 3}$ (SIVmac239 backbone with an HIV-1 subtype B CCR5 tropic envelope [76]), is a virus transmissible in rhesus macaques by mucosal (vaginal and rectal) and parental routes of inoculation.

\section{Simian-tropic HIV (stHIV)}

Animal models may allow for the direct study of drug resistance mutations (DRMs) and their effect on treatment success [77], but there is no model that recreates all aspects of HIV infection in humans [56]. By replacing the HIV-1 capsid (CA) and vif regions of the genome with the corresponding counterparts from SIVmac239 $[\underline{56}, \underline{78}, \underline{79}]$, the HIV-based chimera (stHIV-1 ${ }_{(\mathrm{SCA}, \mathrm{SVIF})}$ ) is capable of infecting human and macaque cell lines by escaping various restriction factors, in particular TRIM5 $\alpha$ and APOBEC3G [56]. Few amino acid substitutions and few silent mutations in the gag and pol genes are present in the chimeric viral construct [56]. Since the active site of the integrase coding region of HIV-1 is conserved in stHIV-1, the latter has been used in studies on INSTIs and DRMs [기.

\section{Integrase Inhibitors}

Animal models have provided important information with regard to the prophylactic efficacy of oral and topical pre-exposure prophylaxis (PrEP) with ARV drugs when animals were challenged through different routes of mucosal exposure. These models have permitted the investigation of parameters that affect ARV efficacy, such as drug resistance, drug pharmacokinetics, and pharmacodynamics.

Early studies showed that EVG suppressed the replication of SIV in vitro and had antiviral activity against SIV (0.5 nM [nanomolar]) [ㅇ]. In vitro studies also showed that SIVmac239 was susceptible to various INSTIs at $\mathrm{nM} \mathrm{IC}$ concentrations, and IN mutant viruses and purified recombinant SIVmac239 IN enzymes displayed similar resistance profiles as did HIV-1 in regard to RAL, EVG, and DTG $[\underline{24}, \underline{54}]$. This has included studies of the major RAL and EVG resistance pathways that include mutations at positions Y143, Q148R, and N155H in IN [24, 54]. DTG was shown to be more potent against IN mutant viruses and purified recombinant SIVmac239 IN enzymes than RAL and EVG $[\underline{24}, \underline{54}]$. Tissue culture selection experiments performed using rhesus peripheral 
blood mononuclear cells (PBMCs) infected with SIVmac239 led to the emergence of R263K and E92Q mutations in IN for DTG and EVG, respectively [24, 54]. R263K is a non-polymorphic mutation that has also been found in several INSTI-naïve ART-experienced patients who received DTG as therapy after failing other drugs [1] and as a secondary mutation after failure with RAL and EVG $[\underline{82}, \underline{83}]$. E92Q has been characterized as a non-polymorphic mutation that can be selected in patients receiving either EVG $[\underline{84-88}]$ or RAL $[\underline{83}, \underline{84}, \underline{89}]$ and is associated with virological failure on EVG-based regimens [요].

Previous in vitro studies have shown that stHIV-1 and HIV-1 also share similarities with regard to the impact of DRMs on resistance against INSTIs and on viral replicative capacity after the introduction of relevant resistance-associated substitutions into stHIV-1 [57]. The G118R and R263K IN substitutions were the most detrimental substitutions regarding stHIV-1 infectivity and replication capacity, which has also been observed for HIV-1 [90-95]. The E92Q, G118R, Y143R, $\mathrm{N} 155 \mathrm{H}$, and R263K substitutions in stHIV-1 conferred similar levels of resistance against INSTIs as in HIV-1 [91-99].

\section{Raltegravir (RAL)}

The efficacy of L-870812, an INSTI, was evaluated in rhesus macaques infected with SHIV $_{89.6 \mathrm{P}}$ and the integrase-coding genes of viruses isolated from both treated and untreated macaques have been sequenced [ [53]. The first report of antiviral activity of an integrase inhibitor (L870812) in SHIV- ${ }_{89.6 \mathrm{P}}$-infected rhesus macaques showed that this drug exhibited antiviral activity against HIV and SIV with $\mathrm{IC}_{95} \mathrm{~s}$ of 250 and $350 \mathrm{nM}$, respectively [ㄷ3]. Macaques treated early with L-870812 exhibited minimal/transient decreases in CD4 cells; four of six animals were virally suppressed to undetectable levels, while the other two treated animals did not achieve suppression but showed no decline in CD4 cell count and maintained low viral loads [53]. In contrast, animals treated later with L-870812 showed both reductions in viral load and decreases in CD4 cell count [53]. In the untreated arm, the integrase coding sequence remained unchanged, whereas $\mathrm{N} 155 \mathrm{H}$-harboring viruses were detected as early as 25 days in the treatment arm in the absence of noticeable viral RNA rebound or CD4 cell depletion [53]. When the $\mathrm{N} 155 \mathrm{H}$ substitution was introduced into an HIV-1 HXB2 plasmid, N155H mutant viruses displayed both drug resistance and a reduction in infectivity [르.

Another study determined the safety of hematopoietic stem cell transplantation in ART-suppressed and unsuppressed animals [100]. In this study, they investigated the development or lack of ARV resistance after bone marrow transplantation in three groups of pigtail macaques treated with a combination of ART that includes RAL (group 1: challenged with SHIV-1157ipd3N4 [R5-tropic SHIV]) but no bone marrow transplant (control group); group 2: transplanted subsequent to SHIV challenge; group 3: challenged with SHIV post-transplant [100]. In the group 3 animals, the $\mathrm{N} 155 \mathrm{H}$ mutation was detected within 3-9 weeks of ART initiation, and the N155H mutation was present in $71 \%$ of total IN sequences [100]. This study has some implications for scheduled treatment interruption studies in patients on ART post-bone marrow transplants, including an incomplete transplant recovery, and potential impaired viral control resulting from premature scheduled treatment interruption that may promote drug resistance [100].

Investigators have also evaluated topical prophylaxis using integrase inhibitors (L-870812 or RAL) in PrEP and post-exposure prophylaxis (PEP) in repeat low-dose vaginal challenge macaque stud- 
ies [101]. To assess the window for inhibition by reverse transcriptase inhibitors and integrase inhibitors, the group performed time of drug addition experiments using HeLa-derived TZMbl cells using a single cycle infection with vesicular stomatitis virus (VSV)-pseudotyped HIV-1 [101]. Reverse transcription occurred 1-2 hours post infection and integration more than 6 hours after infection. In this study, TFV conferred high levels of protection (>95\%) up to 2 hours after infection and $\sim 50 \%$ protection when added 5 hours after infection, while RAL provided high protection levels (>90\%) when given at 6 hours post infection and more than $50 \%$ protection when administered at 10 hours post infection [101]. The authors concluded that INSTIs may be more suitable candidates than reverse transcriptase inhibitors for prophylaxis. RAL was also examined as a topical integrase inhibitor in vivo after vaginal SHIV challenge. During a 10-week follow-up period, five of six macaques treated with RAL gel 3 hours post SHIV exposure remained uninfected, even after 20 weeks, whereas all four macaques that received placebo gel became infected by week 10 [90]. Sequence analysis of the integrase gene of the breakthrough RAL infection revealed wild-type genotypes despite twice weekly dosing for 8 weeks after infection [101]. The group also documented rapid vaginal absorption of RAL demonstrating a short pharmacological lag time; they also noted substantial reductions in vaginal viral load in the breakthrough infection after RAL gel treatment [101]. This study eloquently showed that protection could be achieved and that strand transfer inhibitors have a selective advantage over RT inhibitors since they provide an optimal window for post-coital dosing, which was not a viable option with entry or RT inhibitors $[\underline{102}, \underline{103}]$.

Treatment of SIVmac251 in cultured MT-4 and CEMx174 cell lines by RAL showed inhibition with $\mathrm{IC}_{50 \mathrm{~s}}$ in the low $\mathrm{nM}$ range [25]. RAL-monotherapy (50 or $100 \mathrm{mg}$ RAL twice daily with food) of SIVmac251-infected rhesus macaques for 10 days resulted in a decrease in viral load [25], while the addition of emtricitabine (FTC) and TFV to the treatment led to undetectable viral loads and CD4 cell increases within 2 weeks [25]. However, proviral DNA levels did not change and persisted in PBMCs during the treatment period, indicating the persistence of viral reservoirs [25].

\section{MOUSE STUDIES}

In an early study with humanized mice, L-870812 displayed similar outcomes as in humans, causing suppression of viremia below the limits of viral RNA detection and recovery of $\mathrm{CD} 4^{+} \mathrm{T}$ cells [104]. In this same study, an interruption of ART resulted in viral rebound and loss of CD4 T cells [104]. The authors also reported that treatment failure was associated with the appearance of drug resistance mutations with one of six INSTI-treated mice acquiring mutations associated with RAL resistance at positions D55N, E92Q, E152I, and M154I within IN [104]. As mentioned above, E92Q is a mutation that is associated with resistance to RAL in humans [ $[\underline{83}, \underline{84}, \underline{89}]$. Substitutions at position E152 in IN are significant since this residue is part of the catalytic triad that facilitates binding of $\mathrm{Mg}^{2+}$ to the active site; if the IN viral protein is inactive as a result of mutations at this position, then the integration step will not take place and viral replication may be arrested.

RAL was also examined to determine its potential as a candidate for PrEP [49]. Whereas all of the untreated control infected mice became virus positive within 5 weeks following vaginal challenge with HIV-1 BaL-1, oral administration of RAL fully protected humanized mice [49]. No evidence of infection in treated mice was detected during a 10-week period of evaluation [49]. Moreover, no viral RNA in plasma or proviral DNA in cellular fractions was detected using PCR [누]. 
Recently, the efficacy of long-acting (LA) RAL to protect against vaginal HIV transmission in a PrEP study was investigated. Using transmitted/founder HIV, researchers observed that a single subcutaneous administration of LA RAL to BLT mice provided protection against two high dose HIV challenges at 1 and 4 weeks after drug administration [105]. Researchers also demonstrated penetration of RAL into the female reproductive tract. In addition, these studies documented viral RNA suppression in plasma and in the cervico-vaginal fluids of BLT-infected mice [105]. In mice infected with HIV-1 ${ }_{\mathrm{CH} 040}$ and HIV-1 $1_{\mathrm{RHPA}}$ transmitted/founder (T/F) viruses did not possess detectable mutations were detected in viral DNA derived from plasma. In the case of one infected mouse infected by a HIV-1 $1_{\text {THRO }}$ T/F virus, a single amino acid substitution, I268L, was identified in the integrase gene [105]; although the aforementioned mutation has not previously been associated with RAL resistance [106], one patient receiving RAL treatment did develop a I268M substitution in addition to T97A, Y143R, and other substitutions [107].

Similar trends were seen when studies on mucosal tissue pharmacokinetics of RAL in humanized mice were carried out as in human studies; RAL exhibited higher drug exposure in vaginal and rectal tissues relative to plasma and higher exposure in intestinal mucosa than in plasma [51].

\section{Elvitegravir}

Elvitegravir (EVG) alone is not widely used in animal studies since it was originally approved as part of the fixed dose combination known as Stribild (combination of elvitegravir/cobicistat/ emtricitabine/tenofovir disoproxil fumarate), and researchers were mostly interested in identifying drug resistance, drug pharmacokinetics, and pharmacodynamics of single formulation drugs [8]. However, EVG was recently approved by the FDA as a single pill formulation for ARV-experienced patients [108]. While EVG alone may not have been used in PrEP or monotherapy studies using animal models, pharmacokinetic studies showed that the drug attained higher penetration levels in rectal and vaginal fluids in rhesus macaques despite the absence of pharmacological boosting than were achieved with RAL or DTG [109]. Rectal secretions collected from EVG-treated macaques showed higher antiviral activity than did those from DTG- or RAL-treated mice in TZM-bl cell assays [109].

\section{Cabotegravir}

Cabotegravir (CTG), a DTG analog, is another INSTI currently under development that possesses favorable pharmacokinetics, safety, and efficacy profiles in the clinic [110-112]. While DTG possesses conformational flexibility (6-membered ring) of the metal-chelating scaffold, CTG has a more rigid scaffold (5-membered ring). The half-life of a long-acting (LA) form of CTG was shorter in macaques (3 to 12 days) than in humans (21-50 days) [110, 113]. CTG exhibited high potency against HIV-1 BAL strains in human PBMCs [113]. Due to its high potency, slow metabolism, and highly protein bound, CTG lends itself to use as a LA injectable suitable for monthly to quarterly clinical administration $[\underline{110}, \underline{113}, \underline{114}]$. CTG formulation is also being developed as a single agent for PrEP. In animal studies, the LA form of CTG has been shown to protect macaques from repeated low dose intrarectal SHIV challenges, thereby demonstrating proof of concept of LA CTG in PrEP [115]. Eight macaques were intramuscularly injected with $50 \mathrm{mg} / \mathrm{kg}$ of CTG LA at two time points (before and after challenge) before intrarectal SHIV ${ }_{162 p 3}$ repeated challenge [115]; whereas treated macaques remained aviremic during the challenge and wash-out periods, untreated macaques became infected following challenge [115]. 
Another experiment was performed to determine the minimal drug level needed to achieve protection following low dose intrarectal SHIV challenge. Treated macaques were injected once per week before SHIV challenge, while control macaques did not receive any treatment [115]. Control macaques became infected after 1-2 virus challenges, while treated animals were infected only after 6-17 virus challenges, which coincided with a decline in plasma drug concentrations [115]. Cell-free plasma samples from CTG-treated macaques were also analyzed for integrase amino acid substitutions. Although no primary integrase resistance mutations were observed, substitutions at positions G27R, A122T, E173K, and D256E were detected [115]. It has been postulated that once monthly intramuscular injection of CTG $(50 \mathrm{mg} / \mathrm{kg})$ might be able to reach the same high plasma drug concentrations that are achieved in humans following an 800-mg intramuscular injection [115].

In another experiment, it was shown that a single dose of LA CTG delayed infection in repeated high-dose intravaginally SHIV-challenged macaques [116]. Animals receiving placebo became infected at 1 to 2 weeks post SHIV ${ }_{162 \mathrm{P} 3}$ challenge, whereas protection was observed for 6 of 8 CTG-LA-treated rhesus macaques against three high-dose SHIV challenges (on weeks 1, 5, and 7 following LA CTG intramuscular injection) [116]. Consensus sequence analysis of the SHIV integrase-coding regions from the plasma of infected treated macaques identified P142S and I210V on different genomes at weeks 11 and E198G at week 20. These mutations did not decrease susceptibility to CTG in vitro [116]. Of the three mutations identified, E198 and P142 are both conserved in HIV-1 integrase. Substitutions at positions 198 and 142 have been previously reported in patients receiving RAL $[\underline{89}, \underline{117}, \underline{118}]$.

In agreement with the aforementioned study, another group demonstrated that monthly injections of CTG provided complete protection against repeated intravaginal $\mathrm{SHIV}_{\text {SF162p3 }}$ challenges in pigtail macaques [119]. In this study, female pigtail macaques were intravaginally challenged with SHIV 162P3 twice per week for up to 11 weeks [119]. All of the placebo controls became infected while all macaques that received CTG LA intramuscularly were protected from infection and remained seronegative as well as seronegative for viral RNA and DNA for more than 22 virus challenges [119]. Both of these studies support the clinical development of CTG LA as a PrEP candidate to prevent HIV infection.

\section{CONCLUSIONS}

Animal models have been essential for answering key questions pertaining to antiretroviral therapy, including studies on treatment interruption, tissue biopsies to study cells and tissues, change of regimens, drug resistance-associated mutations, and investigation of novel classes of antiretroviral drugs. Because new anti-HIV drugs still need to be developed to combat drug resistance, the use of non-human primates, humanized mice, and other animal models of viral infection will continue to be essential for this endeavor, as well as for studies on viral pathogenesis.

\section{ACKNOWLEDGMENTS}

Work in our laboratory is supported by research grants from the Canadian Institutes of Health Research (CIHR), including CanCURE, and by the Reseau SIDA of the Fonds de Recherche du Québec. S.A.H. received a doctoral studentship from the Fonds de la Recherché du Québec en Santé (FRQS). 


\section{POTENTIAL CONFLICTS OF INTEREST}

The authors declare that they have no competing interests.

\section{AUTHOR CONTRIBUTIONS}

S.A.H. wrote the manuscript. T.M. helped in reviewing the manuscript. M.A.W. modified and reviewed the manuscript in his role as head of the laboratory. All authors read and approved the final manuscript. 


\section{REFERENCES}

1. Kraus G, Werner A, Baier M, Binniger D, Ferdinand FJ, Norley S, Kurth R. Isolation of human immunodeficiency virus-related simian immunodeficiency viruses from African green monkeys. Proc Natl Acad Sci USA. 1989;86(8):2892-6. PubMed PMID: 2468160. Pubmed Central PMCID: 287025.

2. Ohta Y, Masuda T, Tsujimoto H, Ishikawa K, Kodama T, Morikawa S, Nakai M, Honjo $S$, Hayami M. Isolation of simian immunodeficiency virus from African green monkeys and seroepidemiologic survey of the virus in various non-human primates. Int J Cancer. 1988;41(1):115-22. PubMed PMID: 2447023.

3. Daniel MD, Letvin NL, King NW, Kannagi M, Sehgal PK, Hunt RD, Kanki PJ, Essex $\mathrm{M}$, Desrosiers RC. Isolation of T-cell tropic HTLV-III-like retrovirus from macaques. Science. 1985;228(4704):1201-4. PubMed PMID: 3159089.

4. Letvin NL, Daniel MD, Sehgal PK, Desrosiers RC, Hunt RD, Waldron LM, MacKey JJ, Schmidt DK, Chalifoux LV, King NW. Induction of AIDS-like disease in macaque monkeys with T-cell tropic retrovirus STLV-III. Science. 1985;230(4721):71-3. PubMed PMID: 2412295.

5. Kestler H, Kodama T, Ringler D, Marthas M, Pedersen N, Lackner A, Regier D, Sehgal P, Daniel M, King N, et al. Induction of AIDS in rhesus monkeys by molecularly cloned simian immunodeficiency virus. Science. 1990;248(4959):1109-12. PubMed PMID: 2160735.

6. Letvin NL, Eaton KA, Aldrich WR, Sehgal PK, Blake BJ, Schlossman SF, King NW, Hunt RD. Acquired immunodeficiency syndrome in a colony of macaque monkeys. Proc Natl Acad Sci USA. 1983;80(9):2718-22. PubMed PMID: 6221343. Pubmed Central PMCID: 393899.

7. King NW, Hunt RD, Letvin NL. Histopathologic changes in macaques with an acquired immunodeficiency syndrome (AIDS). Am J Pathol. 1983;113(3):382-8. PubMed PMID: 6316791. Pubmed Central PMCID: 1916356.

8. Hirsch VM, Olmsted RA, Murphey-Corb M, Purcell RH, Johnson PR. An African primate lentivirus (SIVsm) closely related to HIV-2. Nature. 1989;339(6223):389-92. PubMed PMID: 2786147. doi: 10.1038/339389a0

9. Naidu YM, Kestler HW, 3rd, Li Y, Butler CV, Silva DP, Schmidt DK, Troup CD, Sehgal PK, Sonigo P, Daniel MD, et al. Characterization of infectious molecular clones of simian immunodeficiency virus (SIVmac) and human immunodeficiency virus type 2: persistent infection of rhesus monkeys with molecularly cloned SIVmac. J Virol. 1988;62(12):4691-6. PubMed PMID: 2846880. Pubmed Central PMCID: 253583.

10. Gao F, Bailes E, Robertson DL, Chen Y, Rodenburg CM, Michael SF, Cummins LB, Arthur LO, Peeters M, Shaw GM, Sharp PM, Hahn BH. Origin of HIV-1 in the chimpanzee Pan troglodytes troglodytes. Nature. 1999;397(6718):436-41. PubMed PMID: 9989410. doi: 10.1038/17130

11. Hahn BH, Shaw GM, De Cock KM, Sharp PM. AIDS as a zoonosis: scientific and public health implications. Science. 2000;287(5453):607-14. PubMed PMID: 10649986. 
12. Chen Z, Luckay A, Sodora DL, Telfer P, Reed P, Gettie A, Kanu JM, Sadek RF, Yee J, Ho DD, Zhang L, Marx PA. Human immunodeficiency virus type 2 (HIV-2) seroprevalence and characterization of a distinct HIV-2 genetic subtype from the natural range of simian immunodeficiency virus-infected sooty mangabeys. J Virol. 1997;71(5):3953-60. PubMed PMID: 9094672. Pubmed Central PMCID: 191547.

13. Keele BF, Jones JH, Terio KA, Estes JD, Rudicell RS, Wilson ML, Li Y, Learn GH, Beasley TM, Schumacher-Stankey J, Wroblewski E, Mosser A, Raphael J, Kamenya S, Lonsdorf EV, Travis DA, Mlengeya T, Kinsel MJ, Else JG, Silvestri G, Goodall J, Sharp PM, Shaw GM, Pusey AE, Hahn BH. Increased mortality and AIDS-like immunopathology in wild chimpanzees infected with SIVcpz. Nature. 2009;460(7254):515-9. PubMed PMID: 19626114. Pubmed Central PMCID: 2872475. doi: 10.1038/nature08200

14. Hirsch VM, Lifson JD. Simian immunodeficiency virus infection of monkeys as a model system for the study of AIDS pathogenesis, treatment, and prevention. Adv Pharmacol. 2000;49:437-77. PubMed PMID: 11013771.

15. Stone M, Keele BF, Ma ZM, Bailes E, Dutra J, Hahn BH, Shaw GM, Miller CJ. A limited number of simian immunodeficiency virus (SIV) env variants are transmitted to rhesus macaques vaginally inoculated with SIVmac251. J Virol. 2010;84(14):708395. PubMed PMID: 20463069. Pubmed Central PMCID: 2898254. doi: 10.1128/ JVI.00481-10

16. Keele BF, Li H, Learn GH, Hraber P, Giorgi EE, Grayson T, Sun C, Chen Y, Yeh WW, Letvin NL, Mascola JR, Nabel GJ, Haynes BF, Bhattacharya T, Perelson AS, Korber BT, Hahn BH, Shaw GM. Low-dose rectal inoculation of rhesus macaques by SIV smE660 or SIVmac251 recapitulates human mucosal infection by HIV-1. J Exp Med. 2009;206(5):1117-34. PubMed PMID: 19414559. Pubmed Central PMCID: 2715022. doi: $10.1084 /$ jem.20082831

17. Ma ZM, Keele BF, Qureshi H, Stone M, Desilva V, Fritts L, Lifson JD, Miller CJ. SIVmac251 is inefficiently transmitted to rhesus macaques by penile inoculation with a single SIVenv variant found in ramp-up phase plasma. AIDS Res Hum Retroviruses. 2011;27(12):1259-69. PubMed PMID: 21732792. Pubmed Central PMCID: 3227244. doi: 10.1089/aid.2011.0090

18. Abel K, Pahar B, Van Rompay KK, Fritts L, Sin C, Schmidt K, Colon R, McChesney M, Marthas ML. Rapid virus dissemination in infant macaques after oral simian immunodeficiency virus exposure in the presence of local innate immune responses. J Virol. 2006;80(13):6357-67. PubMed PMID: 16775324. Pubmed Central PMCID: 1488945. doi: 10.1128/JVI.02240-05

19. Hazuda DJ, Felock P, Witmer M, Wolfe A, Stillmock K, Grobler JA, Espeseth A, Gabryelski L, Schleif W, Blau C, Miller MD. Inhibitors of strand transfer that prevent integration and inhibit HIV-1 replication in cells. Science. 2000;287(5453):646-50. PubMed PMID: 10649997.

20. Engelman A, Cherepanov P. The structural biology of HIV-1: mechanistic and therapeutic insights. Nat Rev Microbiol. 2012;10(4):279-90. PubMed PMID: 22421880. Pubmed Central PMCID: 3588166. doi: 10.1038/nrmicro2747 
21. Delelis O, Carayon K, Saib A, Deprez E, Mouscadet JF. Integrase and integration: biochemical activities of HIV-1 integrase. Retrovirology. 2008;5:114. PubMed PMID: 19091057. Pubmed Central PMCID: 2615046. doi: 10.1186/1742-4690-5-114

22. Craigie R, Bushman FD. HIV DNA integration. Cold Spring Harb Perspect Med. 2012;2(7):a006890. PubMed PMID: 22762018. Pubmed Central PMCID: 3385939. doi: 10.1101/cshperspect.a006890

23. Grobler JA, Stillmock K, Hu B, Witmer M, Felock P, Espeseth AS, Wolfe A, Egbertson M, Bourgeois M, Melamed J, Wai JS, Young S, Vacca J, Hazuda DJ. Diketo acid inhibitor mechanism and HIV-1 integrase: implications for metal binding in the active site of phosphotransferase enzymes. Proc Natl Acad Sci USA. 2002;99(10):66616. PubMed PMID: 11997448. Pubmed Central PMCID: 124459. doi: 10.1073/ pnas.092056199

24. Hassounah SA, Mesplede T, Quashie PK, Oliveira M, Sandstrom PA, Wainberg MA. The effect of HIV-1 integrase resistance mutations when introduced into SIVmac239 on susceptibility to integrase strand transfer inhibitors. J Virol. 2014. PubMed PMID: 24920794. doi: 10.1128/JVI.00947-14

25. Lewis MG, Norelli S, Collins M, Barreca ML, Iraci N, Chirullo B, Yalley-Ogunro J, Greenhouse J, Titti F, Garaci E, Savarino A. Response of a simian immunodeficiency virus (SIVmac251) to raltegravir: a basis for a new treatment for simian AIDS and an animal model for studying lentiviral persistence during antiretroviral therapy. Retrovirology. 2010;7:21. PubMed PMID: 20233398. Pubmed Central PMCID: 2853490. doi: 10.1186/1742-4690-7-21

26. Hassounah SA, Mesplede T, Quashie PK, Oliveira M, Sandstrom PA, Wainberg MA. Effect of HIV-1 integrase resistance mutations when introduced into SIVmac239 on susceptibility to integrase strand transfer inhibitors. J Virol. 2014;88(17):968392. PubMed PMID: 24920794. Pubmed Central PMCID: 4136349. doi: 10.1128/ JVI.00947-14

27. Sievers F, Wilm A, Dineen D, Gibson TJ, Karplus K, Li W, Lopez R, McWilliam H, Remmert M, Soding J, Thompson JD, Higgins DG. Fast, scalable generation of high-quality protein multiple sequence alignments using Clustal Omega. Mol Syst Biol. 2011;7:539. PubMed PMID: 21988835. Pubmed Central PMCID: 3261699. doi: $10.1038 / \mathrm{msb} .2011 .75$

28. Goujon M, McWilliam H, Li W, Valentin F, Squizzato S, Paern J, Lopez R. A new bioinformatics analysis tools framework at EMBL-EBI. Nucleic Acids Res. 2010;38(Web Server issue):W695-9. PubMed PMID: 20439314. Pubmed Central PMCID: 2896090. doi: $10.1093 /$ nar/gkq313

29. McWilliam H, Li W, Uludag M, Squizzato S, Park YM, Buso N, Cowley AP, Lopez R. Analysis tool web services from the EMBL-EBI. Nucleic Acids Res. 2013;41(Web Server issue):W597-600. PubMed PMID: 23671338. Pubmed Central PMCID: 3692137. doi: 10.1093/nar/gkt376

30. Castagna A, Maggiolo F, Penco G, Wright D, Mills A, Grossberg R, Molina JM, Chas J, Durant J, Moreno S, Doroana M, Ait-Khaled M, Huang J, Min S, Song I, Vavro C, 
Nichols G, Yeo JM. Dolutegravir in antiretroviral-experienced patients with raltegravir- and/or elvitegravir-resistant HIV-1: 24-week results of the phase III VIKING-3 study. J Infect Dis. 2014;210(3):354-62. PubMed PMID: 24446523. Pubmed Central PMCID: 4091579. doi: 10.1093/infdis/jiu051

31. Mamede JI, Sitbon M, Battini JL, Courgnaud V. Heterogeneous susceptibility of circulating SIV isolate capsids to HIV-interacting factors. Retrovirology. 2013;10:77. PubMed PMID: 23883001. Pubmed Central PMCID: 3751554. doi: 10.1186/17424690-10-77

32. Puras Lutzke RA, Eppens NA, Weber PA, Houghten RA, Plasterk RH. Identification of a hexapeptide inhibitor of the human immunodeficiency virus integrase protein by using a combinatorial chemical library. Proc Natl Acad Sci U S A. 1995;92(25):1145660. PubMed PMID: 8524782. Pubmed Central PMCID: 40420.

33. Mazumder A, Neamati N, Ojwang JO, Sunder S, Rando RF, Pommier Y. Inhibition of the human immunodeficiency virus type 1 integrase by guanosine quartet structures. Biochemistry. 1996;35(43):13762-71. PubMed PMID: 8901518. doi: 10.1021/ bi960541u

34. Savarino A, Pistello M, D’Ostilio D, Zabogli E, Taglia F, Mancini F, Ferro S, Matteucci D, De Luca L, Barreca ML, Ciervo A, Chimirri A, Ciccozzi M, Bendinelli M. Human immunodeficiency virus integrase inhibitors efficiently suppress feline immunodeficiency virus replication in vitro and provide a rationale to redesign antiretroviral treatment for feline AIDS. Retrovirology. 2007;4:79. PubMed PMID: 17971219. Pubmed Central PMCID: 2244644. doi: 10.1186/1742-4690-4-79

35. Egberink H, Borst M, Niphuis H, Balzarini J, Neu H, Schellekens H, De Clercq E, Horzinek M, Koolen M. Suppression of feline immunodeficiency virus infection in vivo by 9-(2-phosphonomethoxyethyl)adenine. Proc Natl Acad Sci USA. 1990;87(8):3087-91. PubMed PMID: 2158102. Pubmed Central PMCID: 53839.

36. Matteucci D, Mazzetti P, Baldinotti F, Zaccaro L, Bendinelli M. The feline lymphoid cell line MBM and its use for feline immunodeficiency virus isolation and quantitation. Vet Immunol Immunopathol. 1995;46(1-2):71-82. PubMed PMID: 7618261.

37. Atchison RE, Gosling J, Monteclaro FS, Franci C, Digilio L, Charo IF, Goldsmith MA. Multiple extracellular elements of CCR5 and HIV-1 entry: dissociation from response to chemokines. Science. 1996;274(5294):1924-6. PubMed PMID: 8943208.

38. Kwak YT, Ivanov D, Guo J, Nee E, Gaynor RB. Role of the human and murine cyclin T proteins in regulating HIV-1 tat-activation. J Mol Biol. 1999;288(1):57-69. PubMed PMID: 10329126. doi: 10.1006/jmbi.1999.2664

39. Bosma GC, Custer RP, Bosma MJ. A severe combined immunodeficiency mutation in the mouse. Nature. 1983;301(5900):527-30. PubMed PMID: 6823332.

40. Schuler W, Weiler IJ, Schuler A, Phillips RA, Rosenberg N, Mak TW, Kearney JF, Perry $\mathrm{RP}$, Bosma MJ. Rearrangement of antigen receptor genes is defective in mice with severe combined immune deficiency. Cell. 1986;46(7):963-72. PubMed PMID: 3093081.

41. Berges BK, Akkina SR, Folkvord JM, Connick E, Akkina R. Mucosal transmission of 
R5 and X4 tropic HIV-1 via vaginal and rectal routes in humanized Rag2-/- gammac -/- (RAG-hu) mice. Virology. 2008;373(2):342-51. PubMed PMID: 18207484. Pubmed Central PMCID: 3092740. doi: 10.1016/j.virol.2007.11.020

42. Zhang L, Kovalev GI, Su L. HIV-1 infection and pathogenesis in a novel humanized mouse model. Blood. 2007;109(7):2978-81. PubMed PMID: 17132723. Pubmed Central PMCID: 1852218. doi: 10.1182/blood-2006-07-033159

43. Hartmann K, Donath A, Beer B, Egberink HF, Horzinek MC, Lutz H, Hoffmann-Fezer G, Thum I, Thefeld S. Use of two virustatica (AZT, PMEA) in the treatment of FIV and of FeLV seropositive cats with clinical symptoms. Vet Immunol Immunopathol. 1992;35(1-2):167-75. PubMed PMID: 1363008.

44. Hatziioannou T, Evans DT. Animal models for HIV/AIDS research. Nat Rev Microbiol. 2012;10(12):852-67. PubMed PMID: 23154262. doi: 10.1038/nrmicro2911

45. Auwerx J, Esnouf R, De Clercq E, Balzarini J. Susceptibility of feline immunodeficiency virus/human immunodeficiency virus type 1 reverse transcriptase chimeras to non-nucleoside RT inhibitors. Mol Pharmacol. 2004;65(1):244-51. PubMed PMID: 14722257. doi: 10.1124/mol.65.1.244

46. Shimojima M, Miyazawa T, Ikeda Y, McMonagle EL, Haining H, Akashi H, Takeuchi Y, Hosie MJ, Willett BJ. Use of CD134 as a primary receptor by the feline immunodeficiency virus. Science. 2004;303(5661):1192-5. PubMed PMID: 14976315. doi: 10.1126/ science. 1092124

47. Denton PW, Krisko JF, Powell DA, Mathias M, Kwak YT, Martinez-Torres F, Zou W, Payne DA, Estes JD, Garcia JV. Systemic administration of antiretrovirals prior to exposure prevents rectal and intravenous HIV-1 transmission in humanized BLT mice. PLoS One. 2010;5(1):e8829. PubMed PMID: 20098623. Pubmed Central PMCID: 2809117. doi: 10.1371/journal.pone.0008829

48. Sun Z, Denton PW, Estes JD, Othieno FA, Wei BL, Wege AK, Melkus MW, Padgett-Thomas A, Zupancic M, Haase AT, Garcia JV. Intrarectal transmission, systemic infection, and CD4+ T cell depletion in humanized mice infected with HIV-1. J Exp Med. 2007;204(4):705-14. PubMed PMID: 17389241. Pubmed Central PMCID: 2118553. doi: 10.1084/jem.20062411

49. Neff CP, Ndolo T, Tandon A, Habu Y, Akkina R. Oral pre-exposure prophylaxis by anti-retrovirals raltegravir and maraviroc protects against HIV-1 vaginal transmission in a humanized mouse model. PLoS One. 2010;5(12):e15257. PubMed PMID: 21203568. Pubmed Central PMCID: 3006206. doi: 10.1371/journal.pone.0015257

50. Nischang M, Sutmuller R, Gers-Huber G, Audige A, Li D, Rochat MA, Baenziger S, Hofer U, Schlaepfer E, Regenass S, Amssoms K, Stoops B, Van Cauwenberge A, Boden D, Kraus G, Speck RF. Humanized mice recapitulate key features of HIV-1 infection: a novel concept using long-acting anti-retroviral drugs for treating HIV-1. PLoS One. 2012;7(6):e38853. PubMed PMID: 22719966. Pubmed Central PMCID: 3374767. doi: 10.1371/journal.pone.0038853

51. Veselinovic M, Yang KH, Sykes C, Remling-Mulder L, Kashuba AD, Akkina R. Mucosal tissue pharmacokinetics of the integrase inhibitor raltegravir in a hu- 
manized mouse model: Implications for HIV pre-exposure prophylaxis. Virology. 2016;489:173-8. PubMed PMID: 26771889. doi: 10.1016/j.virol.2015.12.014

52. Whitney JB, Hill AL, Sanisetty S, Penaloza-MacMaster P, Liu J, Shetty M, Parenteau L, Cabral C, Shields J, Blackmore S, Smith JY, Brinkman AL, Peter LE, Mathew SI, Smith KM, Borducchi EN, Rosenbloom DI, Lewis MG, Hattersley J, Li B, Hesselgesser J, Geleziunas R, Robb ML, Kim JH, Michael NL, Barouch DH. Rapid seeding of the viral reservoir prior to SIV viraemia in rhesus monkeys. Nature. 2014;512(7512):747. PubMed PMID: 25042999. Pubmed Central PMCID: 4126858. doi: 10.1038/nature13594

53. Hazuda DJ, Young SD, Guare JP, Anthony NJ, Gomez RP, Wai JS, Vacca JP, Handt L, Motzel SL, Klein HJ, Dornadula G, Danovich RM, Witmer MV, Wilson KA, Tussey L, Schleif WA, Gabryelski LS, Jin L, Miller MD, Casimiro DR, Emini EA, Shiver JW. Integrase inhibitors and cellular immunity suppress retroviral replication in rhesus macaques. Science. 2004;305(5683):528-32. PubMed PMID: 15247437. doi: 10.1126/ science. 1098632

54. Hassounah SA, Liu Y, Quashie PK, Oliveira M, Moisi D, Brenner BG, Sandstrom PA, Mesplede T, Wainberg MA. Characterization of the drug resistance profiles of integrase strand transfer inhibitors in simian immunodeficiency virus SIVmac239. J Virol. 2015;89(23):12002-13. PubMed PMID: 26378179. Pubmed Central PMCID: 4645305. doi: 10.1128/JVI.02131-15

55. Witvrouw M, Pannecouque C, Switzer WM, Folks TM, De Clercq E, Heneine W. Susceptibility of HIV-2, SIV and SHIV to various anti-HIV-1 compounds: implications for treatment and postexposure prophylaxis. Antivir Ther. 2004;9(1):57-65. PubMed PMID: 15040537.

56. Hatziioannou T, Princiotta M, Piatak M, Jr., Yuan F, Zhang F, Lifson JD, Bieniasz PD. Generation of simian-tropic HIV-1 by restriction factor evasion. Science. 2006;314(5796):95. PubMed PMID: 17023652. doi: 10.1126/science.1130994

57. Wares M, Hassounah S, Mesplede T, Sandstrom PA, Wainberg MA. Simian-tropic $\mathrm{HIV}$ as a model to study drug resistance against integrase inhibitors. Antimicrob Agents Chemother. 2015;59(4):1942-9. PubMed PMID: 25583721. Pubmed Central PMCID: 4356797. doi: 10.1128/AAC.04829-14

58. Knight A. The beginning of the end for chimpanzee experiments? Philos Ethics Humanit Med. 2008;3:16. PubMed PMID: 18518999. Pubmed Central PMCID: 2432070. doi: 10.1186/1747-5341-3-16

59. Bettauer RH. Chimpanzees in hepatitis C virus research: 1998-2007. J Med Primatol. 2010;39(1):9-23. PubMed PMID: 19900169. doi: 10.1111/j.1600-0684.2009.00390.x

60. Blakley GB, Beamer TW, Dukelow WR. Characteristics of the menstrual cycle in nonhuman primates. IV. Timed mating in Macaca nemestrina. Lab Anim. 1981;15(4):3513. PubMed PMID: 7341846.

61. Wira CR, Fahey JV. A new strategy to understand how HIV infects women: identification of a window of vulnerability during the menstrual cycle. AIDS. 2008;22(15):190917. PubMed PMID: 18784454. Pubmed Central PMCID: 2647143. doi: 10.1097/ 
QAD.0b013e3283060ea4

62. Vishwanathan SA, Guenthner PC, Lin CY, Dobard C, Sharma S, Adams DR, Otten RA, Heneine W, Hendry RM, McNicholl JM, Kersh EN. High susceptibility to repeated, low-dose, vaginal SHIV exposure late in the luteal phase of the menstrual cycle of pigtail macaques. J Acquir Immune Defic Syndr. 2011;57(4):261-4. PubMed PMID: 21546848. doi: 10.1097/QAI.0b013e318220ebd3

63. Sodora DL, Gettie A, Miller CJ, Marx PA. Vaginal transmission of SIV: assessing infectivity and hormonal influences in macaques inoculated with cell-free and cell-associated viral stocks. AIDS Res Hum Retroviruses. 1998;14 Suppl 1:S119-23. PubMed PMID: 9581895.

64. Zhou Y, Bao R, Haigwood NL, Persidsky Y, Ho WZ. SIV infection of rhesus macaques of Chinese origin: a suitable model for HIV infection in humans. Retrovirology. 2013;10:89. PubMed PMID: 23947613. Pubmed Central PMCID: 3765527. doi: 10.1186/1742-4690-10-89

65. Otten RA, Adams DR, Kim CN, Jackson E, Pullium JK, Lee K, Grohskopf LA, Monsour M, Butera S, Folks TM. Multiple vaginal exposures to low doses of R5 simian-human immunodeficiency virus: strategy to study HIV preclinical interventions in nonhuman primates. J Infect Dis. 2005;191(2):164-73. PubMed PMID: 15609225. doi: $10.1086 / 426452$

66. Livingston L, Sweeney E, Mitchell J, Luo W, Paul K, Powell N, Michael Hendry R, McNicholl J, Kersh E. Hormonal synchronization of the menstrual cycles of pigtail macaques to facilitate biomedical research including modeling HIV susceptibility. J Med Primatol. 2011;40(3):164-70. PubMed PMID: 21241313. doi: 10.1111/j.16000684.2010.00465.x

67. Pilcher CD, Tien HC, Eron JJ, Jr., Vernazza PL, Leu SY, Stewart PW, Goh LE, Cohen MS. Brief but efficient: acute HIV infection and the sexual transmission of HIV. J Infect Dis. 2004;189(10):1785-92. PubMed PMID: 15122514. doi: 10.1086/386333

68. Dobard C, Sharma S, Martin A, Pau CP, Holder A, Kuklenyik Z, Lipscomb J, Hanson DL, Smith J, Novembre FJ, Garcia-Lerma JG, Heneine W. Durable protection from vaginal simian-human immunodeficiency virus infection in macaques by tenofovir gel and its relationship to drug levels in tissue. J Virol. 2012;86(2):718-25. PubMed PMID: 22072766. Pubmed Central PMCID: 3255839. doi: 10.1128/JVI.05842-11

69. Li J, Lord CI, Haseltine W, Letvin NL, Sodroski J. Infection of cynomolgus monkeys with a chimeric HIV-1/SIVmac virus that expresses the HIV-1 envelope glycoproteins. J Acquir Immune Defic Syndr. 1992;5(7):639-46. PubMed PMID: 1613662.

70. Riddick NE, Hermann EA, Loftin LM, Elliott ST, Wey WC, Cervasi B, Taaffe J, Engram JC, Li B, Else JG, Li Y, Hahn BH, Derdeyn CA, Sodora DL, Apetrei C, Paiardini M, Silvestri G, Collman RG. A novel CCR5 mutation common in sooty mangabeys reveals SIVsmm infection of CCR5-null natural hosts and efficient alternative coreceptor use in vivo. PLoS Pathog. 2010;6(8):e1001064. PubMed PMID: 20865163. Pubmed Central PMCID: 2928783. doi: 10.1371/journal.ppat.1001064

71. Evans DT, Silvestri G. Nonhuman primate models in AIDS research. Curr Opin 
HIV AIDS. 2013;8(4):255-61. PubMed PMID: 23615116. Pubmed Central PMCID: 3987953. doi: 10.1097/COH.0b013e328361cee8

72. Chen Z, Yan Y, Munshi S, Li Y, Zugay-Murphy J, Xu B, Witmer M, Felock P, Wolfe A, Sardana V, Emini EA, Hazuda D, Kuo LC. X-ray structure of simian immunodeficiency virus integrase containing the core and C-terminal domain (residues 50-293)-an initial glance of the viral DNA binding platform. J Mol Biol. 2000;296(2):521-33. PubMed PMID: 10669606. doi: 10.1006/jmbi.1999.3451

73. Li Y, Yan Y, Zugay-Murphy J, Xu B, Cole JL, Witmer M, Felock P, Wolfe A, Hazuda D, Sardana MK, Chen Z, Kuo LC, Sardana VV. Purification, solution properties and crystallization of SIV integrase containing a continuous core and C-terminal domain. Acta Crystallogr D Biol Crystallogr. 1999;55(Pt 11):1906-10. PubMed PMID: 10531491.

74. Reimann KA, Li JT, Veazey R, Halloran M, Park IW, Karlsson GB, Sodroski J, Letvin NL. A chimeric simian/human immunodeficiency virus expressing a primary patient human immunodeficiency virus type 1 isolate env causes an AIDS-like disease after in vivo passage in rhesus monkeys. J Virol. 1996;70(10):6922-8. PubMed PMID: 8794335. Pubmed Central PMCID: 190741.

75. Feinberg MB, Moore JP. AIDS vaccine models: challenging challenge viruses. Nat Med. 2002;8(3):207-10. PubMed PMID: 11875482. doi: 10.1038/nm0302-207

76. Harouse JM, Gettie A, Tan RC, Blanchard J, Cheng-Mayer C. Distinct pathogenic sequela in rhesus macaques infected with CCR5 or CXCR4 utilizing SHIVs. Science. 1999;284(5415):816-9. PubMed PMID: 10221916.

77. Van Rompay KK. Evaluation of antiretrovirals in animal models of HIV infection. Antiviral Res. 2010;85(1):159-75. PubMed PMID: 19622373. doi: 10.1016/j.antiviral.2009.07.008

78. Kamada K, Igarashi T, Martin MA, Khamsri B, Hatcho K, Yamashita T, Fujita M, Uchiyama T, Adachi A. Generation of HIV-1 derivatives that productively infect macaque monkey lymphoid cells. Proc Natl Acad Sci USA. 2006;103(45):1695964. PubMed PMID: 17065315. Pubmed Central PMCID: 1622925. doi: 10.1073/ pnas.0608289103

79. Na L, Tang YD, Liu JD, Yu CQ, Sun LK, Lin YZ, Wang XF, Wang X, Zhou JH. TRIMe7-CypA, an alternative splicing isoform of TRIMCyp in rhesus macaque, negatively modulates TRIM5alpha activity. Biochem Biophys Res Commun. 2014;446(2):470-4. PubMed PMID: 24613845. doi: 10.1016/j.bbrc.2014.02.132

80. Shimura K, Kodama E, Sakagami Y, Matsuzaki Y, Watanabe W, Yamataka K, Watanabe Y, Ohata Y, Doi S, Sato M, Kano M, Ikeda S, Matsuoka M. Broad antiretroviral activity and resistance profile of the novel human immunodeficiency virus integrase inhibitor elvitegravir (JTK-303/GS-9137). J Virol. 2008;82(2):764-74. PubMed PMID: 17977962. Pubmed Central PMCID: 2224569. doi: 10.1128/JVI.01534-07

81. Cahn P, Pozniak AL, Mingrone H, Shuldyakov A, Brites C, Andrade-Villanueva JF, Richmond G, Buendia CB, Fourie J, Ramgopal M, Hagins D, Felizarta F, Madruga J, Reuter T, Newman T, Small CB, Lombaard J, Grinsztejn B, Dorey D, Underwood M, Griffith S, Min S. Dolutegravir versus raltegravir in antiretroviral-experienced, inte- 
grase-inhibitor-naive adults with HIV: week 48 results from the randomised, double-blind, non-inferiority SAILING study. Lancet. 2013;382(9893):700-8. PubMed PMID: 23830355. doi: 10.1016/S0140-6736(13)61221-0

82. Margot NA, Hluhanich RM, Jones GS, Andreatta KN, Tsiang M, McColl DJ, White $\mathrm{KL}$, Miller MD. In vitro resistance selections using elvitegravir, raltegravir, and two metabolites of elvitegravir M1 and M4. Antiviral Res. 2012;93(2):288-96. PubMed PMID: 22197635. doi: 10.1016/j.antiviral.2011.12.008

83. Blanco JL, Varghese V, Rhee SY, Gatell JM, Shafer RW. HIV-1 integrase inhibitor resistance and its clinical implications. J Infect Dis. 2011;203(9):1204-14. PubMed PMID: 21459813. Pubmed Central PMCID: 3069732. doi: 10.1093/infdis/jir025

84. Hatano H, Lampiris H, Fransen S, Gupta S, Huang W, Hoh R, Martin JN, Lalezari J, Bangsberg D, Petropoulos C, Deeks SG. Evolution of integrase resistance during failure of integrase inhibitor-based antiretroviral therapy. J Acquir Immune Defic Syndr. 2010;54(4):389-93. PubMed PMID: 20300008. Pubmed Central PMCID: 2890029. doi: 10.1097/QAI.0b013e3181c42ea4

85. Van Wesenbeeck L, Rondelez E, Feyaerts M, Verheyen A, Van der Borght K, Smits V, Cleybergh C, De Wolf H, Van Baelen K, Stuyver LJ. Cross-resistance profile determination of two second-generation HIV-1 integrase inhibitors using a panel of recombinant viruses derived from raltegravir-treated clinical isolates. Antimicrob Agents Chemother. 2011;55(1):321-5. PubMed PMID: 20956600. Pubmed Central PMCID: 3019647. doi: 10.1128/AAC.01733-09

86. Winters MA, Lloyd RM, Jr., Shafer RW, Kozal MJ, Miller MD, Holodniy M. Development of elvitegravir resistance and linkage of integrase inhibitor mutations with protease and reverse transcriptase resistance mutations. PLoS One. 2012;7(7):e40514. PubMed PMID: 22815755. Pubmed Central PMCID: 3399858. doi: 10.1371/journal. pone.0040514

87. DeJesus E, Rockstroh JK, Lennox JL, Saag MS, Lazzarin A, Zhao J, Wan H, Rodgers AJ, Walker ML, Miller M, DiNubile MJ, Nguyen BY, Teppler H, Leavitt R, Sklar P. Efficacy of raltegravir versus efavirenz when combined with tenofovir/emtricitabine in treatment-naive HIV-1-infected patients: week-192 overall and subgroup analyses from STARTMRK. HIV Clin Trials. 2012;13(4):228-32. PubMed PMID: 22849964. doi: $10.1310 /$ hct1304-228

88. Sax PE, DeJesus E, Mills A, Zolopa A, Cohen C, Wohl D, Gallant JE, Liu HC, Zhong L, Yale K, White K, Kearney BP, Szwarcberg J, Quirk E, Cheng AK. Co-formulated elvitegravir, cobicistat, emtricitabine, and tenofovir versus co-formulated efavirenz, emtricitabine, and tenofovir for initial treatment of HIV-1 infection: a randomised, double-blind, phase 3 trial, analysis of results after 48 weeks. Lancet. 2012;379(9835):2439-48. PubMed PMID: 22748591. doi: 10.1016/S01406736(12)60917-9

89. Molina JM, Lamarca A, Andrade-Villanueva J, Clotet B, Clumeck N, Liu YP, Zhong L, Margot N, Cheng AK, Chuck SL. Efficacy and safety of once daily elvitegravir versus twice daily raltegravir in treatment-experienced patients with HIV-1 receiving a ri- 
tonavir-boosted protease inhibitor: randomised, double-blind, phase 3, non-inferiority study. Lancet Infect Dis. 2012;12(1):27-35. PubMed PMID: 22015077. doi: 10.1016/ S1473-3099(11)70249-3

90. Quashie PK, Mesplede T, Han YS, Oliveira M, Singhroy DN, Fujiwara T, Underwood MR, Wainberg MA. Characterization of the R263K mutation in HIV-1 integrase that confers low-level resistance to the second-generation integrase strand transfer inhibitor dolutegravir. J Virol. 2012;86(5):2696-705. PubMed PMID: 22205735. Pubmed Central PMCID: 3302270. doi: 10.1128/JVI.06591-11

91. Quashie PK, Mesplede T, Han YS, Veres T, Osman N, Hassounah S, Sloan RD, Xu HT, Wainberg MA. Biochemical analysis of the role of G118R-linked dolutegravir drug resistance substitutions in HIV-1 integrase. Antimicrob Agents Chemother. 2013;57(12):6223-35. PubMed PMID: 24080645. Pubmed Central PMCID: 3837891. doi: 10.1128/AAC.01835-13

92. Quashie PK, Oliviera M, Veres T, Osman N, Han YS, Hassounah S, Lie Y, Huang W, Mesplede T, Wainberg MA. Differential effects of the G118R, H51Y, and E138K resistance substitutions in different subtypes of HIV integrase. J Virol. 2015;89(6):316375. PubMed PMID: 25552724. Pubmed Central PMCID: 4337543. doi: 10.1128/ JVI.03353-14

93. Mesplede T, Quashie PK, Hassounah S, Osman N, Han Y, Liang J, Singhroy DN, Wainberg MA. The R263K substitution in HIV-1 subtype $\mathrm{C}$ is more deleterious for integrase enzymatic function and viral replication than in subtype B. AIDS. 2015;29(12):145966. PubMed PMID: 26244385. doi: 10.1097/QAD.0000000000000752

94. Mesplede T, Quashie PK, Osman N, Han Y, Singhroy DN, Lie Y, Petropoulos CJ, Huang W, Wainberg MA. Viral fitness cost prevents HIV-1 from evading dolutegravir drug pressure. Retrovirology. 2013;10:22. PubMed PMID: 23432922. Pubmed Central PMCID: 3598531. doi: 10.1186/1742-4690-10-22

95. Abram ME, Hluhanich RM, Goodman DD, Andreatta KN, Margot NA, Ye L, Niedziela-Majka A, Barnes TL, Novikov N, Chen X, Svarovskaia ES, McColl DJ, White KL, Miller MD. Impact of primary elvitegravir resistance-associated mutations in HIV1 integrase on drug susceptibility and viral replication fitness. Antimicrob Agents Chemother. 2013;57(6):2654-63. PubMed PMID: 23529738. Pubmed Central PMCID: 3716146. doi: 10.1128/AAC.02568-12

96. Anstett K, Fusco R, Cutillas V, Mesplede T, Wainberg MA. Dolutegravir-selected HIV1 containing the N155H/R263K resistance substitutions does not acquire additional compensatory mutations under drug pressure that lead to higher level resistance and increased replicative capacity. J Virol. 2015. PubMed PMID: 26246578. doi: 10.1128/ JVI.01725-15

97. Anstett K, Mesplede T, Oliveira M, Cutillas V, Wainberg MA. Dolutegravir resistance mutation R263K cannot coexist in combination with many classical integrase inhibitor resistance substitutions. J Virol. 2015;89(8):4681-4. PubMed PMID: 25653436. Pubmed Central PMCID: 4442391.doi: 10.1128/JVI.03485-14

98. Yoshinaga T, Kobayashi M, Seki T, Miki S, Wakasa-Morimoto C, Suyama-Kagitani A, 
Kawauchi-Miki S, Taishi T, Kawasuji T, Johns BA, Underwood MR, Garvey EP, Sato A, Fujiwara T. Antiviral characteristics of GSK1265744, an HIV integrase inhibitor dosed orally or by long-acting injection. Antimicrob Agents Chemother. 2015;59(1):397406. PubMed PMID: 25367908. Pubmed Central PMCID: 4291378. doi: 10.1128/ AAC.03909-14

99. Kobayashi M, Yoshinaga T, Seki T, Wakasa-Morimoto C, Brown KW, Ferris R, Foster SA, Hazen RJ, Miki S, Suyama-Kagitani A, Kawauchi-Miki S, Taishi T, Kawasuji T, Johns BA, Underwood MR, Garvey EP, Sato A, Fujiwara T. In vitro antiretroviral properties of S/GSK1349572, a next-generation HIV integrase inhibitor. Antimicrob Agents Chemother. 2011;55(2):813-21. PubMed PMID: 21115794. Pubmed Central PMCID: 3028777. doi: 10.1128/AAC.01209-10

100. Peterson CW, Haworth KG, Polacino P, Huang ML, Sykes C, Obenza WM, Repetto AC, Kashuba A, Bumgarner R, DeRosa SC, Woolfrey AE, Jerome KR, Mullins JI, Hu SL, Kiem HP. Lack of viral control and development of combination antiretroviral therapy escape mutations in macaques after bone marrow transplantation. AIDS. 2015;29(13):1597-606. PubMed PMID: 26372270. Pubmed Central PMCID: 4572605. doi: 10.1097/QAD.0000000000000702

101. Dobard C, Sharma S, Parikh UM, West R, Taylor A, Martin A, Pau CP, Hanson DL, Lipscomb J, Smith J, Novembre F, Hazuda D, Garcia-Lerma JG, Heneine W. Postexposure protection of macaques from vaginal SHIV infection by topical integrase inhibitors. Sci Transl Med. 2014;6(227):227ra35. PubMed PMID: 24622515. doi: 10.1126/ scitranslmed.3007701

102. Kenney J, Singer R, Derby N, Aravantinou M, Abraham CJ, Menon R, Seidor S, Zhang S, Gettie A, Blanchard J, Piatak M, Jr., Lifson JD, Fernandez-Romero JA, Zydowsky TM, Robbiani M. A single dose of a MIV-150/Zinc acetate gel provides $24 \mathrm{~h}$ of protection against vaginal simian human immunodeficiency virus reverse transcriptase infection, with more limited protection rectally 8-24 h after gel use. AIDS Res Hum Retroviruses. 2012;28(11):1476-84. PubMed PMID: 22737981. Pubmed Central PMCID: 3484818. doi: 10.1089/AID.2012.0087

103. Cranage M, Sharpe S, Herrera C, Cope A, Dennis M, Berry N, Ham C, Heeney J, Rezk N, Kashuba A, Anton P, McGowan I, Shattock R. Prevention of SIV rectal transmission and priming of $\mathrm{T}$ cell responses in macaques after local pre-exposure application of tenofovir gel. PLoS Med. 2008;5(8):e157; discussion e. PubMed PMID: 18684007. Pubmed Central PMCID: 2494562. doi: 10.1371/journal.pmed.0050157

104. Choudhary SK, Rezk NL, Ince WL, Cheema M, Zhang L, Su L, Swanstrom R, Kashuba AD, Margolis DM. Suppression of human immunodeficiency virus type 1 (HIV-1) viremia with reverse transcriptase and integrase inhibitors, CD4+ T-cell recovery, and viral rebound upon interruption of therapy in a new model for HIV treatment in the humanized Rag2-/-\{gamma\}c-/- mouse. J Virol. 2009;83(16):8254-8. PubMed PMID: 19494021. Pubmed Central PMCID: 2715775. doi: 10.1128/JVI.00580-09

105. Kovarova M, Swanson MD, Sanchez RI, Baker CE, Steve J, Spagnuolo RA, Howell BJ, Hazuda DJ, Garcia JV. A long-acting formulation of the integrase inhibitor raltegravir protects humanized BLT mice from repeated high-dose vaginal HIV challenges. J An- 
timicrob Chemother. 2016. PubMed PMID: 27002074. doi: 10.1093/jac/dkw042

106. Garrido C, Villacian J, Zahonero N, Pattery T, Garcia F, Gutierrez F, Caballero E, Van Houtte M, Soriano V, de Mendoza C. Broad phenotypic cross-resistance to elvitegravir in $\mathrm{HIV}$-infected patients failing on raltegravir-containing regimens. Antimicrob Agents Chemother. 2012;56(6):2873-8. PubMed PMID: 22450969. Pubmed Central PMCID: 3370736. doi: 10.1128/AAC.06170-11

107. Sichtig N, Sierra S, Kaiser R, Daumer M, Reuter S, Schulter E, Altmann A, Fatkenheuer G, Dittmer U, Pfister H, Esser S. Evolution of raltegravir resistance during therapy. J Antimicrob Chemother. 2009;64(1):25-32. PubMed PMID: 19447792. doi: $10.1093 / \mathrm{jac} / \mathrm{dkp} 153$

108. Elvitegravir (Vitekta) for HIV. Med Lett Drugs Ther. 2016;58(1486):10-1. PubMed PMID: 26761343.

109. Massud I, Martin A, Dinh C, Mitchell J, Jenkins L, Heneine W, Pau CP, Garcia-Lerma JG. Pharmacokinetic profile of raltegravir, elvitegravir and dolutegravir in plasma and mucosal secretions in rhesus macaques. J Antimicrob Chemother. 2015;70(5):147381. PubMed PMID: 25630643. Pubmed Central PMCID: 4398473. doi: 10.1093/jac/ dku556

110. Spreen W, Min S, Ford SL, Chen S, Lou Y, Bomar M, St Clair M, Piscitelli S, Fujiwara T. Pharmacokinetics, safety, and monotherapy antiviral activity of GSK1265744, an HIV integrase strand transfer inhibitor. HIV Clin Trials. 2013;14(5):192-203. PubMed PMID: 24144896. doi: 10.1310/hct1405-192

111. Andrews CD, Heneine W. Cabotegravir long-acting for HIV-1 prevention. Curr Opin HIV AIDS. 2015;10(4):258-63. PubMed PMID: 26049951. doi: 10.1097/ COH.0000000000000161

112. Trezza C, Ford SL, Spreen W, Pan R, Piscitelli S. Formulation and pharmacology of long-acting cabotegravir. Curr Opin HIV AIDS. 2015;10(4):239-45. PubMed PMID: 26049948. doi: 10.1097/COH.0000000000000168

113. Spreen WR, Margolis DA, Pottage JC, Jr. Long-acting injectable antiretrovirals for HIV treatment and prevention. Curr Opin HIV AIDS. 2013;8(6):565-71. PubMed PMID: 24100877. Pubmed Central PMCID: 3815009. doi: 10.1097/COH.0000000000000002

114. Johns BA, Kawasuji T, Weatherhead JG, Taishi T, Temelkoff DP, Yoshida H, Akiyama T, Taoda Y, Murai H, Kiyama R, Fuji M, Tanimoto N, Jeffrey J, Foster SA, Yoshinaga T, Seki T, Kobayashi M, Sato A, Johnson MN, Garvey EP, Fujiwara T. Carbamoyl pyridone HIV-1 integrase inhibitors 3. A diastereomeric approach to chiral nonracemic tricyclic ring systems and the discovery of dolutegravir (S/GSK1349572) and (S/ GSK1265744). J Med Chem. 2013;56(14):5901-16. PubMed PMID: 23845180. doi: $10.1021 / \mathrm{jm} 400645 \mathrm{w}$

115. Andrews CD, Spreen WR, Mohri H, Moss L, Ford S, Gettie A, Russell-Lodrigue K, Bohm RP, Cheng-Mayer C, Hong Z, Markowitz M, Ho DD. Long-acting integrase inhibitor protects macaques from intrarectal simian/human immunodeficiency virus. Science. 2014;343(6175):1151-4. PubMed PMID: 24594934. Pubmed Central PMCID: 4308974. doi: 10.1126/science. 1248707 
116. Andrews CD, Yueh YL, Spreen WR, St Bernard L, Boente-Carrera M, Rodriguez K, Gettie A, Russell-Lodrigue K, Blanchard J, Ford S, Mohri H, Cheng-Mayer C, Hong Z, Ho DD, Markowitz M. A long-acting integrase inhibitor protects female macaques from repeated high-dose intravaginal SHIV challenge. Sci Transl Med. 2015;7(270):270ra4. PubMed PMID: 25589630. Pubmed Central PMCID: 4449736. doi: $10.1126 /$ scitranslmed.3010298

117. Hurt CB, Sebastian J, Hicks CB, Eron JJ. Resistance to HIV integrase strand transfer inhibitors among clinical specimens in the United States, 2009-2012. Clin Infect Dis. 2014;58(3):423-31. PubMed PMID: 24145878. Pubmed Central PMCID: 3890334. doi: $10.1093 / \mathrm{cid} / \mathrm{cit} 697$

118. Cavalcanti Jde S, Ferreira JL, Guimaraes PM, Vidal JE, Brigido LF. High frequency of dolutegravir resistance in patients failing a raltegravir-containing salvage regimen. J Antimicrob Chemother. 2015;70(3):926-9. PubMed PMID: 25386009. doi: 10.1093/ jac/dku439

119. Radzio J, Spreen W, Yueh YL, Mitchell J, Jenkins L, Garcia-Lerma JG, Heneine W. The long-acting integrase inhibitor GSK744 protects macaques from repeated intravaginal SHIV challenge. Sci Transl Med. 2015;7(270):270ra5. PubMed PMID: 25589631. doi: 10.1126/scitranslmed.3010297

\section{COPYRIGHT}

(C) Pathogens and Immunity 2017

This work is licensed under a Creative Commons Attribution 4.0 International License. To view a copy of this license, visit http://creativecommons.org/licenses/by/4.0/ 